\title{
Anxiety and Depression During COVID-19 Pandemic Among Medical Students in Nepal
}

\author{
Ajay Risal ( $\sim$ drajayrisal@gmail.com ) \\ Kathmandu University School of Medical Sciences https://orcid.org/0000-0002-1352-858X \\ Shreeja Shikhrakar \\ Kathmandu University School of Medical Sciences \\ Sachin Mishra \\ Kathmandu University School of Medical Sciences \\ Dipak Kunwar \\ Kathmandu University School of Medical Sciences \\ Eliza Karki \\ Kathmandu University School of Medical Sciences \\ Barsha Shrestha \\ Kathmandu University School of Medical Sciences \\ Shubekshya Khadka \\ Kathmandu University School of Medical Sciences \\ Are Holen \\ Norwegian University of Science and Technology: Norges teknisk-naturvitenskapelige universitet
}

\section{Research}

Keywords: anxiety, covid-19, depression, medical students, pandemic, self-quarantine

Posted Date: October 15th, 2020

DOI: https://doi.org/10.21203/rs.3.rs-91574/v1

License: (c) (i) This work is licensed under a Creative Commons Attribution 4.0 International License. Read Full License 


\section{Abstract}

Background: Medical students' psychological response to societal lockdown during the covid-19 pandemic has not been studied much. Our aim was to assess levels of anxiety and depression among medical students during the initial stages of the pandemic in Nepal and relate their distress to psychosocial and other relevant situational variables.

Materials and Methods: A cross-sectional study with an online questionnaire was conducted among medical students at different colleges in Nepal. Hospital Anxiety and Depression Scale (HADS) detected manifestations of anxiety and depression. The covariates were explored by logistic regression analyses.

Results: A total 416 medical students [mean age: 22.2 (2.1); males 57.7\%, females 42.3\%] participated. HADS-anxiety scores [mean: 7.1(4.3)] were significantly and positively correlated with HADS-depression [mean: $5.9(4.1)$ ] $(r=0.695 ; p<0.001)$. Point prevalence of total HADS caseness (HADS-T) was 26.7\%. Specific HADS-defined caseness were: anxiety (HADS-A) $11.8 \%$, depression (HADS-D) 5.5\%, and comorbid anxiety and depression (HADS-CAD) 9.4\%. All four types of caseness were significantly more prevalent among students with a history of mental problems (AOR=4.7, 3.2, 2.6, and 3.2 respectively). HADS-T was higher among those with a concurrent physical illness (AOR=2.4). HADS-T, HADS-A and HADS-D scores were higher among the age group $>22$ years (AOR= 2.2, 2.5 and 4.4 respectively). HADS-CAD was almost three-times higher among those with a possible COVID-19 exposure (AOR=2.8).

Conclusion: A significant number of medical students in Nepal suffered from high levels of anxiety and depression during the covid-19 shutdown. The students in the higher ( $>22$ years) age group, those with past mental disorders, a possible covid-19 exposure, and a concurrent physical illness showed elevated levels of anxiety and/or depression.

\section{Introduction}

Corona virus belongs to a large family that causes symptoms ranging from a common cold to a severe acute respiratory syndrome (SARS). A new strain (covid-19) was isolated in China in December 2019. This strain is now spreading worldwide[1]. On 11 March 2020, this viral infection was declared by WHO - World Health Organization to be a pandemic. Social distancing, frequent hand washing, and self-quarantine have been suggested as adequate measures to limit the disease $[2,3]$. The virus is major threat to the life, health and to the economy of the individual, family and society.

Social distancing includes isolation, quarantine, shelter-in-place, or protective sequestration. Isolation refers to separation of those diagnosed or infected from the uninfected, whereas quarantine is the separation of healthy individuals, who may have been or can be exposed to infective agents [4, 5]. Social distancing etc. can have adverse psychosocial consequences [6].

During prior pandemics, a variety of psychological problems like depression, anxiety, and post-traumatic stress disorder (PTSD) have been reported, but also other emotional responses such as anger, irritability, insomnia, low self-esteem, loneliness, boredom, and fear [7]. In the 2003 SARS outbreak in Canada, quarantined individuals including health-workers experienced heightened psychological distress [8]. Similar experiences were reported from Singapore [9].

Other international studies about those quarantined or isolated during the current corona virus disease (covid-19) pandemic have shown similar forms of psychological responses [10-12]. An online survey carried out at different cities in China during the initial stages of covid-19 revealed that more than half of the participants reported some anxiety, depression and stress [13]. Psychological effects of the lockdown have been reported from India [14]. There are also reports about heightened distress among the mentally ill in the pandemic areas [15]. Increased alcohol or substance withdrawal has also been seen [16]. Furthermore, mounting suicide rates raise public health concern [17, 18]. The effects of the pandemic on childhood and adolescent mental health cannot be overlooked [19].

In order to combat the covid-19, the Government of Nepal imposed an almost 4 months (March-July 2020) nation-wide complete lockdown [20]. The strategy was later changed to a partial lockdown or shutdown in affected districts or municipalities [20]. In Nepal, a few studies indicate psychological consequences of the lockdown [21-24].

Loss of varied daily routines, less physical activity and social contacts may have led to boredom and frustrations. These changes have been regarded as major precipitators of psychological distress during the lockdown [6]. Adolescents and youth, especially college students seem to have been hit hard when their educational institutions closed $[25,26]$. Medical students are generally confronted with significant academic and career-related stressors; they appear to be more prone to stress and burnout-related complaints [27, 28]. Studies of possible psychiatric manifestations among medical students during the covid-19 pandemic are mostly lacking. 
Considering these facts, we aimed to assess signs of depression and anxiety among the undergraduate medical students in Nepal as possible manifestations of psychological distress during the covid-19 outbreak. We aimed for a better understanding of how pandemics or infectious epidemics as stressors may affect the mental condition of medical students. We see this as a starting point for lessening the mental burden now and in the future in relation to similar events.

\section{Material And Methods}

Ethics: This is an online cross-sectional, quantitative study of undergraduate medical students pursuing Bachelor in Medicine and Bachelor in Surgery (MBBS) courses at different Medical Colleges in Nepal. The study has been approved by the Institutional Review Committee of Kathmandu University School of Medical Sciences (IRC-KUSMS) (Approval number 59/20).

Survey questionnaire: Data collection was done through an online survey using google-forms. It was distributed via online forums and social media at the medical colleges. All respondents were asked to give written informed consent before starting.

The variables below were explored in this study:

1. Participant's demographic status: age (later dichotomized based on the mean value), and gender (male or female).

2. Name of medical college; current year of MBBS study, later dichotomized into the pre-clinical (year 1 and 2 ) and clinical phase (year 3 and above).

3. Health status: presence of any concurrent physical illnesses (yes or no) at the time of the study; history of a mental disorder (yes or no).

4. Covid-19 related questions:

a. History of possible covid-19 exposure (yes or no).

b. Quarantine location: at home with family, or self-quarantine in some other location like student hostels, home of relatives, or rented domicile (home or other).

c. Number of days in self-quarantine, calculated by subtracting the date of initiating the quarantine from the date of the online interview.

d. Adequacy of basic needs: the students' subjective assessment of their situation regarding access to basic needs (food, water, clothing etc.) rated on a scale from 1 to 10; 1 indicated the least and 10, the maximum during the self-quarantine.

Instrument: Manifestations of anxiety and depression were assessed using the Hospital Anxiety and Depression Scale (HADS) [29]. The HADS contains 14 items with seven in each of two subscales: HADS-anxiety and HADS-depression (A1 to A7; D1 to D7). The reliability in terms of internal consistency of the two subscales in this study was indicated by Cronbach alpha, 0.84 and 0.80 respectively for anxiety and depression. Each item addressed the participants' subjective self-report of the preceding week. The item is rated on a four-point scale from $0-$ 3 (3 indicating maximum severity). Each subscale is a sum score with the potential range from 0 to 21 . As recommended, we used 11 as the threshold to indicate caseness for anxiety (HADS-A) or depression (HADS-D) [29, 30].

Procedure: Medical undergraduates (first to fifth year MBBS) willing to take part both in the study and to complete the online questionnaire were included.

Based on a prior study, the required sample size was calculated from the reported prevalence of anxiety and depression among medical students in Nepal at that time [28]. Allowing for $10 \%$ of potential non-responders, the calculated sample size was 414 .

Participants: Total 416 participants consented and completed satisfactorily the online survey. Around one-thirds (28.8\%) was from Kathmandu University School of Medical Sciences (KUSMS) and around two-fifths (17.3\%) from the Institute of Medicine (IOM). Other medical colleges with high frequencies of participants were: Nobel Medical College (8.9\%), BP Koirala Institute of Health Sciences (7\%), Chitwan Medical College (6.7\%), Lumbini Medical College (5.5\%), and Nepal Medical College (5\%).

Statistical Analysis: Data analysis was done by using SPSS version 25. Responses on the google form were transferred via Excel into SPSS. Descriptive statistic was used for the demographic variables.

The point-prevalence of caseness for anxiety and depression was established by HADS and reported as percentages with 95\% confidence intervals (Cls). Participants who scored above the threshold ( $\geq 11)$ on both subscales were categorized as cases of comorbid anxiety and depression (HADS-CAD). Those scoring above the threshold only on the HADS-anxiety subscale were considered anxiety cases (HADS-A) while those scoring $\geq 11$ only on the HADS-depression subscale were considered to be depression cases (HADS-D) [31]. Ultimately, the point prevalence of all four types of HADS caseness together (HADS-T) were calculated in the same manner.

Page $3 / 11$ 
Pearson's Correlation was used to explore relationships between the total scores of HADS-anxiety and HADS-depression subscales, and their independent associations with the continuous variables: days in self-quarantine and the adequacy of basic needs.

Logistic regression analysis was used to study the covariates in relation to each of the four types of caseness derived from HADS. The four dependent variables were: HADS-T, HADS-A, HADS-D, and HADS-CAD. The independent variables were age, gender, study phase, history of covid-19 exposure, history of mental disorders, and concurrent physical illnesses. Continuous variables were also entered in the regression equation. Adjusted Odd's ratio (AOR) with 95\% Cl was calculated. Significance level was considered at $p<0.05$.

\section{Results}

The participants' age ranged from 17 to 30 years; mean age being 22.2 (2.1). This variable was dichotomized into above and below 22 years. Almost three-fourths of them were males (57.7\%). More than three-fifths (64.7\%) were in the clinical phase of the study.

Regarding mental health, around three-fourths (76.4\%) reported never to have had a psychiatric disorder. Among the $23.6 \%$ who reported some psychiatric problems in their past, $13.5 \%$ had suffered from anxiety and $8.2 \%$ had depression. Below one-tenth (7.5\%) had a concurrent physical illness other than covid-19 at the time of the study.

Regarding covid-19, 89.7\% did not report any exposure that they were aware of. Among the $10.3 \%$ who reported a possible exposure, $6.3 \%$ regarded their family members or close relatives as the probable source. In order to maintain self-quarantine, around four-fifths of the participants (78.8\%) stayed at home with their families (Table 1).

Table 1

Participant information $(\mathrm{N}=416)$

\begin{tabular}{|lc|}
\hline Variables & \multicolumn{1}{|c|}{ Number (\%) } \\
\hline 1.Age (in years)* & \\
\hline 22 years and below & $212(51.0)$ \\
\hline Above 22 years & $204(49.0)$ \\
\hline 2. Gender & \\
\hline Male & $240(57.7)$ \\
\hline Female & $176(42.3)$ \\
\hline 3. Phase of study & $147(35.3)$ \\
\hline Pre-clinical & $269(64.7)$ \\
\hline Clinical & $318(76.4)$ \\
\hline 4. History of mental disorder \\
\hline No & $38(21.2)$ \\
\hline Yes & $98(23.6)$ \\
\hline 5. Concurrent physical illness \\
\hline No & $385(92.5)$ \\
\hline Yes & $31(7.5)$ \\
\hline 6. History of possible covid-19 exposure \\
\hline No
\end{tabular}


Almost three-fourths of the participants (73.3\%) did not qualify for any psychiatric caseness according to the HADS screening. Among those with caseness, $11.8 \%$ had HADS defined anxiety (HADS-A), 5.5\% had depression (HADS-D), and $9.4 \%$ were suffering from comorbid anxiety and depression (HADS-CAD) (Table 2).

Table 2

Point prevalences of HADS-defined psychiatric caseness $(\mathrm{N}=416)$

\begin{tabular}{|llll|}
\hline Caseness * & Number & $\%(95 \% \mathrm{Cl})$ \\
\hline Anxiety (HADS-A) & 49 & $11.8(8.8-15.3)$ \\
\hline Depression (HADS-D) & 23 & $5.5(3.5-8.2)$ \\
\hline Comorbid anxiety and Depression (HADS-CAD) & 39 & $9.4(6.7-12.6)$ \\
\hline No case & 305 & $73.3(68.8-77.5)$ \\
\hline *Total HADS caseness (HADS-T = HADS-A + HADS-D + HADS-CAD) $=111(26.7 \%)$ \\
\hline
\end{tabular}

The mean scores of the HADS-anxiety and HADS-depression subscales were respectively 7.1 (SD 4.3) and 5.9 (SD 4.1 ); the two sub-scales were significantly and positively correlated $(r=0.695 ; p<0.001)$. The mean number of days in self-quarantine was 59.8 , the median was 17 and the mode was 14, and the range went from 0 to 231 days. The self-assessed mean score for the adequacy of basic needs was 8.5 (1.8).

HADS-anxiety was significantly and positively correlated with the days in self-quarantine $(r=0.137 ; p=0.005)$ and negatively correlated with adequacy of basic needs $(r=-0.106 ; p=0.031)$. HADS-depression was negatively correlated with the adequacy of basic needs $(r=-0.168 ; p=$ $0.001)$.

In the multivariate logistic regression analyses, HADS-T caseness was significantly more frequent among the participants above 22 years $(A O R=2.2 ; p=0.021)$, among those with a history mental disorder ( $A O R=4.7 ; p<0.001)$, and among those with a concurrent physical illnesses $(A O R=2.4 ; p=0.034)$ at the time of the study.

Regarding the specific caseness, HADS-A was significantly more frequent among participants above 22 years $(A O R=2.5 ; p=0.046)$ and those with a history of mental disorder $(A O R=3.2 ; p<0.001)$. HADS-D caseness was also more frequent among those with age $>22$ years $(A O R=$ $4.4 ; p=0.038$ ) and those with a history of mental disorder ( $A O R=2.6 ; p=0.041)$. HADS-cAD was more frequent among those with a possible history of covid-19 exposure (AOR = 2.8; $p=0.02)$, and those with a history of mental disorder $(A O R=3.2 ; p=0.002)(S e e$ Table 3$)$. 
Table 3

Multivariate logistic regression analyses: Exploring associations of independent variables in relation to HADS caseness. Dependent variables: any psychiatric caseness, HADS-A, HADS-D and HADS-CAD.

\begin{tabular}{|c|c|c|c|c|c|c|c|c|c|c|c|c|}
\hline \multirow{4}{*}{$\begin{array}{l}\text { Caseness } \\
\text { Variables }\end{array}$} & \multicolumn{3}{|c|}{$\begin{array}{l}\text { Any HADS caseness, total } \\
(n=111)\end{array}$} & \multicolumn{3}{|c|}{ HADS-A $(n=49)$} & \multicolumn{3}{|c|}{ HADS-D $(n=23)$} & \multicolumn{3}{|c|}{ HADS-CAD $(n=39)$} \\
\hline & \multirow[t]{3}{*}{$\mathrm{n}(\%)$} & \multicolumn{2}{|c|}{$\begin{array}{l}\text { Multivariate } \\
\text { analyses }\end{array}$} & \multirow[t]{3}{*}{$n(\%)$} & \multicolumn{2}{|c|}{$\begin{array}{l}\text { Multivariate } \\
\text { analyses }\end{array}$} & \multirow[t]{3}{*}{$\mathrm{n}(\%)$} & \multicolumn{2}{|c|}{$\begin{array}{l}\text { Multivariate } \\
\text { analyses }\end{array}$} & \multirow[t]{3}{*}{$\mathrm{n}(\%)$} & \multicolumn{2}{|c|}{$\begin{array}{l}\text { Multivariate } \\
\text { analyses }\end{array}$} \\
\hline & & AOR* & $p$ & & $\mathrm{AOR}^{*}$ & $\mathbf{P}$ & & $\mathrm{AOR}^{*}$ & $p$ & & $\mathrm{AOR}^{*}$ & $\mathrm{p}$ \\
\hline & & $(95 \% \mathrm{Cl})$ & & & $(95 \% \mathrm{Cl})$ & & & $(95 \% \mathrm{Cl})$ & & & $(95 \% \mathrm{Cl})$ & \\
\hline \multicolumn{13}{|c|}{ Age (in years) } \\
\hline $\begin{array}{l}22 \text { and } \\
\text { below }\end{array}$ & $\begin{array}{l}49 \\
(44.1)\end{array}$ & Reference & - & $\begin{array}{l}19 \\
(38.8)\end{array}$ & Reference & - & $\begin{array}{l}8 \\
(34.8)\end{array}$ & reference & - & $\begin{array}{l}22 \\
(56.4)\end{array}$ & reference & - \\
\hline 22 years & $\begin{array}{l}62 \\
(55.9)\end{array}$ & $\begin{array}{l}2.2(1.1- \\
4.4)\end{array}$ & 0.021 & $\begin{array}{l}30 \\
(61.2)\end{array}$ & $\begin{array}{l}2.5(1.0- \\
6.4)\end{array}$ & 0.046 & $\begin{array}{l}15 \\
(65.2)\end{array}$ & $\begin{array}{l}4.4(1.1- \\
17.7)\end{array}$ & 0.038 & $\begin{array}{l}17 \\
(43.6)\end{array}$ & $\begin{array}{l}0.8(0.3- \\
1.9)\end{array}$ & 0.59 \\
\hline \multicolumn{13}{|l|}{ Gender } \\
\hline Male & $\begin{array}{l}56 \\
(50.5)\end{array}$ & Reference & - & $\begin{array}{l}25 \\
(51.0)\end{array}$ & Reference & - & $\begin{array}{l}14 \\
(60.9)\end{array}$ & reference & - & $\begin{array}{l}17 \\
(43.6)\end{array}$ & reference & - \\
\hline Female & $\begin{array}{l}55 \\
(49.5)\end{array}$ & $\begin{array}{l}1.6 \\
(0.98- \\
2.7)\end{array}$ & 0.060 & $\begin{array}{l}24 \\
(49.0)\end{array}$ & $\begin{array}{l}1.5(0.8- \\
2.8)\end{array}$ & 0.242 & $\begin{array}{l}9 \\
(39.1)\end{array}$ & $\begin{array}{l}0.8(0.3- \\
2.1)\end{array}$ & 0.686 & $\begin{array}{l}22 \\
(56.4)\end{array}$ & $\begin{array}{l}1.7(0.8- \\
3.7)\end{array}$ & 0.146 \\
\hline \multicolumn{13}{|c|}{ Phase of study } \\
\hline $\begin{array}{l}\text { Pre- } \\
\text { clinical }\end{array}$ & $\begin{array}{l}39 \\
(35.1)\end{array}$ & Reference & - & $\begin{array}{l}16 \\
(32.7)\end{array}$ & Reference & - & $\begin{array}{l}8 \\
(34.8)\end{array}$ & reference & - & $\begin{array}{l}15 \\
(38.5)\end{array}$ & reference & - \\
\hline Clinical & $\begin{array}{l}72 \\
(64.9)\end{array}$ & $\begin{array}{l}0.7(0.3- \\
1.3)\end{array}$ & 0.254 & $\begin{array}{l}33 \\
(67.3)\end{array}$ & $\begin{array}{l}0.6(0.2- \\
1.6)\end{array}$ & 0.317 & $\begin{array}{l}15 \\
(65.2)\end{array}$ & $\begin{array}{l}0.4 \\
(0.09- \\
1.5)\end{array}$ & 0.160 & $\begin{array}{l}24 \\
(61.5)\end{array}$ & $\begin{array}{l}1.1(0.4- \\
2.9)\end{array}$ & 0.800 \\
\hline \multicolumn{13}{|c|}{ History of possible covid-19 exposure } \\
\hline No & $\begin{array}{l}94 \\
(84.7)\end{array}$ & Reference & - & $\begin{array}{l}43 \\
(87.8)\end{array}$ & Reference & - & $\begin{array}{l}22 \\
(95.7)\end{array}$ & reference & - & $\begin{array}{l}29 \\
(74.4)\end{array}$ & reference & - \\
\hline Yes & $\begin{array}{l}17 \\
(15.3)\end{array}$ & $\begin{array}{l}1.5(0.7- \\
3.0)\end{array}$ & 0.31 & $\begin{array}{l}6 \\
(12.2)\end{array}$ & $\begin{array}{l}0.9(0.3- \\
2.4)\end{array}$ & 0.839 & $\begin{array}{l}1 \\
(4.3)\end{array}$ & $\begin{array}{l}0.4 \\
(0.05- \\
3.2)\end{array}$ & 0.400 & $\begin{array}{l}10 \\
(25.6)\end{array}$ & $\begin{array}{l}2.8(1.2- \\
6.9)\end{array}$ & 0.02 \\
\hline \multicolumn{13}{|c|}{ Quarantine location } \\
\hline $\begin{array}{l}\text { At home } \\
\text { with } \\
\text { family }\end{array}$ & $\begin{array}{l}88 \\
(79.3)\end{array}$ & Reference & - & $\begin{array}{l}36 \\
(73.5)\end{array}$ & Reference & - & $\begin{array}{l}20 \\
(87.0)\end{array}$ & reference & - & $\begin{array}{l}32 \\
(82.1)\end{array}$ & reference & - \\
\hline $\begin{array}{l}\text { Other } \\
\text { locations }\end{array}$ & $\begin{array}{l}23 \\
(20.7)\end{array}$ & $\begin{array}{l}0.7(0.4- \\
1.4)\end{array}$ & 0.38 & $\begin{array}{l}13 \\
(26.5)\end{array}$ & $\begin{array}{l}1.3(0.6- \\
2.7)\end{array}$ & 0.533 & $\begin{array}{l}3 \\
(13.0)\end{array}$ & $\begin{array}{l}0.4(0.1- \\
1.8)\end{array}$ & 0.280 & $7(17.9)$ & $\begin{array}{l}0.6(0.2- \\
1.6)\end{array}$ & 0.304 \\
\hline \multicolumn{13}{|c|}{ History of Mental Disorder } \\
\hline No & $\begin{array}{l}59 \\
(53.2)\end{array}$ & Reference & - & $\begin{array}{l}26 \\
(53.1)\end{array}$ & Reference & - & $\begin{array}{l}13 \\
(56.5)\end{array}$ & reference & - & $\begin{array}{l}20 \\
(51.3)\end{array}$ & reference & - \\
\hline Yes & $\begin{array}{l}52 \\
(46.8)\end{array}$ & $\begin{array}{l}4.7(2.7- \\
8.0)\end{array}$ & $\hat{0} .001$ & $\begin{array}{l}23 \\
(46.9)\end{array}$ & $\begin{array}{l}3.2(1.7- \\
6.2)\end{array}$ & $\hat{0.001}$ & $\begin{array}{l}10 \\
(43.5)\end{array}$ & $\begin{array}{l}2.6(1.0- \\
6.6)\end{array}$ & 0.041 & $\begin{array}{l}19 \\
(48.7)\end{array}$ & $\begin{array}{l}3.2(1.5- \\
6.7)\end{array}$ & 0.002 \\
\hline \multicolumn{13}{|c|}{ Concurrent Physical Illnesses } \\
\hline No & $\begin{array}{l}95 \\
(85.6)\end{array}$ & Reference & - & $\begin{array}{l}43 \\
(87.8)\end{array}$ & Reference & - & $\begin{array}{l}19 \\
(82.6)\end{array}$ & reference & - & $33(84.6)$ & reference & - \\
\hline Yes & $\begin{array}{l}16 \\
(14.4)\end{array}$ & $\begin{array}{l}2.4(1.1- \\
5.4)\end{array}$ & 0.034 & $\begin{array}{l}6 \\
(12.2)\end{array}$ & $\begin{array}{l}1.4(0.5- \\
3.9)\end{array}$ & 0.482 & $\begin{array}{l}4 \\
(17.4)\end{array}$ & $\begin{array}{l}2.2(0.6- \\
7.6)\end{array}$ & 0.197 & $6(15.4)$ & $\begin{array}{l}2.2(0.8- \\
6.2)\end{array}$ & 0.132 \\
\hline
\end{tabular}


This online survey indicates that almost one-third of the medical students in Nepal are mentally affected by covid-19 as a stressor in their daily lives. This applies even to those with no experience of exposure to covid-19. As a stressor, the virus represents a major unseen threat to life and to the health of the students, their families, friends, and community.

During the pandemic outbreak, the students' levels of anxiety and depression go up. Around one-tenth score above the thresholds for comorbid anxiety and depression; and this group of students reported a high degree of possible covid-19 exposure. The potential contact with the virus leads to the highest reported distress in this population. The finding underscores the "dose-response" link between stressor exposure and the distress levels. Moreover, it is publicly well known that those who die from covid-19 often have an additional diagnosis [32]. In our study, those with a concurrent physical illness have higher occurrence of the comorbid HADS caseness.

Regarding caseness for anxiety only, more than $10 \%$ score above the threshold, and $5.5 \%$ do so for depression only. The frequency of anxiety cases is twice that of the depressive ones. In the stress paradigm when faced with threats, arousal, sympathetic activation of the fight-flight mode is the expected response, which is closely related to anxiety [33]. The high correlation between anxiety and depression among the students is in line with findings of a high co-occurrence of the two related to PTSD [34].

In their short lives, $13.5 \%$ of the medical students reported anxiety-related mental problems in the past, and $8.2 \%$ depression. In terms of point prevalence at the outbreak of the pandemic by means of HADS, $11.8 \%$ showed caseness of anxiety and $5.5 \%$ displayed caseness for depression. When looking at the figures from these two sources - past and now - the first figures reflect the numbers from an extended time period while the other is a momentary measure. Fear of infection among students may be one probable explanation for the high point prevalence found [6]

The Nepali government enforced social-distancing in addition to the shutdown and later a complete or partial lockdown in areas to combat the spread of the virus [20]. Schools, colleges and universities have been closed since March 2020, and most people including students are staying at home in self-quarantine. These restrictions may have been more stressful among the medical students in the higher classes, i.e., those in higher age bracket ( $>22$ years) displayed more anxiety and depression than their younger fellow students. With higher age and maturity, they may have recognized more fully what the covid-19 pandemic may entail. In addition, sedentary habits due to prolonged lockdown may have contributed to psychological distress [25].

Few or no classes and insufficient online teaching may have escalated the already high academic stresses of medical students and increased the uncertainty about their academic future [28]. Nepalese medical students tend to enjoy directly supervised teaching-learning rather than self-studies. A prior comparative study of medical students showed that a self-administered or non-authoritarian learning format was culturally less popular among the Nepalese students than in Western countries [35].

In the binary analysis, the number of days of self-quarantine was positively linked to the levels of anxiety. The perception of their adequacy of basic needs was negatively correlated with both anxiety and depression. These facts are in keeping with findings in a review which underscored that the length of the quarantine and insufficient basic living conditions or facilities, were linked to a negative psychological outcome [6]. However, the days in quarantine and the adequacy of basic needs did not emerge with significance in the multivariate analyses.

However, there were clear links between a history of mental problems and the medical students' current levels of distress. This is in line with a case-control study from the hospital designated for covid-19 patients in China; it showed higher anxiety and depression scores among psychiatric patients than in healthy controls [15].Within the stress paradigm, research findings have shown that those with former anxiety and/or depression problems are more PTSD prone when exposed to major stressors [34, 36].

High prevalence of anxiety and depression in general among the adult population in Nepal has been well documented in a nationwide study [31]. The recent global burden of disease (GBD) survey data revealed depression and anxiety to be among the top ten disabling conditions in the world; extrapolated data in South Asia and Nepal also support these findings [37]. Higher degrees of general psychological distress in the form of anxiety and depression have also been reported among medical students in Nepal $[27,28]$. The current global pandemic has added a sense of threat with surmounting stress $[6,11]$. The levels of stress have gone up among college students, who during the pandemic were isolated in their homes, perhaps suffering from boredom and frustrations, loneliness due to limited social activities and learning opportunities. In addition comes the escalating academic and career-oriented uncertainties and pressures $[25,26]$.

An online survey in Nepal among healthcare workers involved in the pandemic revealed high levels of anxiety in almost $40 \%$ and depression in the $8 \%$ of the participants [21]. These healthcare workers were predominantly younger (mean age 29.5), close in age to the medical students. Another study assessing the psychological impacts of the lockdown in Nepal showed $25.4 \%$ of the participants to have anxiety and $7 \%$ reporting depression [22]. The findings of both studies are relevant, as the majority of the participants were doctors, and the participants in our study are the 'future doctors'. 
The study has some limitations. Being cross-sectional research, cause-effect relationships cannot be established. The population of medical students is not a representative drawn sample. However, the medical students form a fairly homogeneous group with regard to age and sociodemographic status, and in our study, they come from colleges from several parts of the country. Probably this makes the studied sample not too different from a representative sample. The findings may not easily be generalized to the general population but more likely to other kinds of health workers.

Face-to-face diagnostic interviews would have been preferable for establishing the frequencies of psychiatric disorders. However, that procedure for data collection would not have been advisable during the current pandemic. HADS has clearly demonstrated to be a valid screening instrument, both internationally [38] and in Nepal [30]. In this study, it indicates that the medical students experience an increase in mental burden in the context of the covid-19 pandemic. The above-mentioned national [21, 22, 24] and international [15, 25] studies also used online surveys; previous research has demonstrated that online surveys function as well as paper-and-pencil surveys [39]. In addition; online studies are safer for all parties during a pandemic. Also, online surveys are more convenient for the informant as they can choose the time and location for responding, which is assumed to lower the threshold for participating. Another issue of concern may be the self-rating of the adequacy of basic needs, which is an entirely a subjective expression.

Despite these limitations, we were able to form an understanding about the psychological impact of covid-19 as a mental stressor in a sample of medical students in Nepal. These students, being a literate group, were easily amenable for an online survey and self-administration of the $\operatorname{HADS}[29,30]$. The findings of this study call for a coordinated health strategy with special emphasis on upholding the mental health of health workers during times of a pandemic. Society is particularly dependent on their work in crisis of this kind.

\section{Conclusions}

A good number of medical students in Nepal suffer from higher levels of anxiety and depression during this phase of covid-19 shut-down. The students in the higher (> 22 years) age group, those with more days in self-quarantine, those with inadequate resources for daily living, those with a history of mental health problems or a concurrent physical illness, and a possible covid-19 exposure history are at higher risk of psychological distress in a pandemic.

\section{Abbreviations}

\begin{tabular}{|ll|}
\hline AOR & Adjusted Odd's ratio \\
\hline covid-19 & Coronavirus Disease 2019 \\
\hline GBD & global burden of disease \\
HADS & Hospital Anxiety and Depression Scale \\
\hline IOM & Institute of Medicine \\
\hline IRC-KUSMS: & Institutional Review Committee of Kathmandu University School of Medical Sciences \\
\hline KUSMS & Kathmandu University School of Medical Sciences \\
\hline MBBS & Bachelor in Medicine and Bachelor in Surgery \\
\hline PTSD & post-traumatic stress disorder \\
\hline SARS & severe acute respiratory syndrome \\
\hline WHO: & World Health Organization \\
\hline
\end{tabular}

\section{Declarations}

\section{Ethics approval and consent to participate}

The Institutional Review Committee of the Kathmandu University School of Medical Sciences (IRC-KUSMS), Dhulikhel Hospital, Kavre, Nepal approved the study protocol. Before the online response, written informed consent was given by each participant.

\section{Consent for publication}


The google-sheet spread among the participants contained all information about the study. The information described the nature and purpose of the study. The information sheet clearly stated that those who participated also gave their consent to utilise de-identified data for scientific and popular paper publications.

\section{Availability of data and material}

Personal identification details of the participants were separated from the completed questionnaires and stored in a locked room at the Kathmandu University School of Medical Sciences (KUSMS). No information relating to identifiable individuals was disseminated beyond the few researchers immediately involved in the study.

The data sets used and/or analyzed during the current study are available from the corresponding author on reasonable request.

\section{Competing interests}

None

\section{Funding}

None

\section{Authors' contributions}

AR and SS were involved in the conception and design of the study. SS and SM were responsible for the data acquisition. AR, with the support from $\mathrm{AH}$, performed the data analysis and interpretation. AR drafted the initial manuscript, and also, he did the necessary modifications for making the manuscript acceptable for publication. All authors revised the manuscript critically for intellectual content and approved the submitted version.

\section{Acknowledgments}

We would like to thank all the participating medical students for the information that made this study possible.

\section{References}

1. Khot WY, Nadkar MY. The 2019 Novel Coronavirus Outbreak - A Global Threat. J Assoc Physicians India. 2020; 68(3):67-71.

2. WHO Timeline - COVID-19. WHO. 2020. https://www.who.int/news-room/detail/29-06-2020-covidtimeline. Accessed 18 Aug 2020.

3. Islam N, Sharp SJ, Chowell G, Shabnam S, Kawachi I, Lacey B, et al. Physical distancing interventions and incidence of coronavirus disease 2019: natural experiment in 149 countries. BMJ. 2020; 370:m2743.

4. When to Quarantine. Coronavirus Disease 2019 (COVID-19). CDC. 2019. https://www.cdc.gov/coronavirus/2019-ncov/if-you-aresick/quarantine.html . Accessed 18 Aug 2020.

5. Huremović D. Social Distancing, Quarantine, and Isolation. In: Huremović D, Psychiatry of Pandemics: A Mental Health Response to Infection Outbreak [ebook], editor. Cham: Springer International Publishing; 2019. p. 85-94. Available from: https://doi.org/10.1007/9783-030-15346-5_8. Accessed 18 Aug 2020.

6. Brooks SK, Webster RK, Smith LE, Woodland L, Wessely S, Greenberg N, Rubin GJ. The psychological impact of quarantine and how to reduce it: rapid review of the evidence. The Lancet. 2020; 395(10227):912-20.

7. Hossain MM, Sultana A, Purohit N. Mental health outcomes of quarantine and isolation for infection prevention: a systematic umbrella review of the global evidence. Epidemiol Health. 2020;42:e2020038. doi:10.4178/epih.e2020038.

8. Reynolds DL, Garay JR, Deamond SL, Moran MK, Gold W, Styra R. Understanding, compliance and psychological impact of the SARS quarantine experience. Epidemiol Infect. 2007; 136(7):997-1007.

9. Sim K, Huak Chan Y, Chong PN, Chua HC, Wen Soon S. Psychosocial and coping responses within the community health care setting towards a national outbreak of an infectious disease. J Psychosom Res. 2010; 68(2):195-202.

10. Rajkumar RP. COVID-19 and mental health: A review of the existing literature. Asian J Psychiatr. 2020; 52:102066.

Page $9 / 11$ 
11. Salari N, Hosseinian-Far A, Jalali R, Vaisi-Raygani A, Rasoulpoor S, Mohammadi M, et al. Prevalence of stress, anxiety, depression among the general population during the COVID-19 pandemic: a systematic review and meta-analysis. Globalization and Health. $2020 ; 16(1): 57$.

12. Ho CS, Chee CY, Ho RC. Mental Health Strategies to Combat the Psychological Impact of COVID-19 Beyond Paranoia and Panic. Ann Acad Med Singapore. 2020; 49(3):155-160.

13. Wang C, Pan R, Wan X, Tan Y, Xu L, Ho CS. Immediate Psychological Responses and Associated Factors during the Initial Stage of the 2019 Coronavirus Disease (COVID-19) Epidemic among the General Population in China. Int. J. Environ. Res. Public Health. 2020; 17, 1729. doi:10.3390/ijerph17051729.

14. Hiremath P, Suhas Kowshik CS, Manjunath M, Shettar M. COVID 19: Impact of lock-down on mental health and tips to overcome. Asian J Psychiatr. 2020; 51:102088.

15. Hao F, Tan W, Jiang L, Zhang L, Zhao X, Zou Y, et al. Do psychiatric patients experience more psychiatric symptoms during COVID-19 pandemic and lockdown? A case-control study with service and research implications for immunopsychiatry. Brain Behav Immun. 2020; 87:100-06.

16. Narasimha VL, Shukla L, Mukherjee D, Menon J, Huddar S, Panda UK, et al. Complicated Alcohol Withdrawal-An Unintended Consequence of COVID-19 Lockdown. Alcohol Alcohol. 2020; 55(4):350-3.

17. Gunnell D, Appleby L, Arensman E, Hawton K, John A, Kapur N, et al. Suicide risk and prevention during the COVID-19 pandemic. The Lancet Psychiatry. 2020; 7(6):468-71.

18. Risal A. Psychological interventions may prevent suicide [article in Nepali]. Kantipur Daily. June 30, 2020. https://ekantipur.com/opinion/2020/06/30/159348546372172460.html? fbclid=IwAR1PajXSEiYLtRJgRSLJ7c8MYEpjbGIpu4zX0MAsSYiil4bFurRM2la2fSg. Accessed 18 Aug 2020.

19. Sharma V, Reina Ortiz M, Sharma N. Risk and Protective Factors for Adolescent and Young Adult Mental Health Within the Context of COVID-19: A Perspective From Nepal. J Adolesc Health. 2020; 67(1):135-7.

20. The Government of Nepal; Ministry of Health and Population. Situation report of COVID-19. 2020. https://covid19.mohp.gov.np/? fbclid=IwAR0c3mbZplCdnkDipWiM-XS3RICJQzECLhLrBs47tzw3NCl6SBPCGyhXHa8\#/. Accessed 18 Aug 2020.

21. Gupta AK, Mehra A, Niraula A, Kafle K, Deo SP, Singh B, et al. Prevalence of anxiety and depression among the healthcare workers in Nepal during the COVID-19 pandemic. Asian J Psychiatr. 2020; 54:102260-102260.

22. Gupta AK, Sahoo S, Mehra A, Grover S. Psychological impact of 'Lockdown' due to COVID-19 pandemic in Nepal: An online survey. Asian J Psychiatr. 2020; 54:102243.

23. Poudel K, Subedi P. Impact of COVID-19 pandemic on socioeconomic and mental health aspects in Nepal. Int J Soc Psychiatry. 2020;0020764020942247.

24. Khanal P, Devkota N, Dahal M, Paudel K, Joshi D. Mental health impacts among health workers during COVID-19 in a low resource setting: a cross-sectional survey from Nepal. Globalization and Health. 2020; 16(1):89.

25. Huckins JF, DaSilva AW, Wang W, Hedlund E, Rogers C, Nepal SK, et al. Mental Health and Behavior of College Students During the Early Phases of the COVID-19 Pandemic: Longitudinal Smartphone and Ecological Momentary Assessment Study. J Med Internet Res. 2020; 22(6):e20185. URL: https://www.jmir.org/2020/6/e20185.

26. Dartmouth College. "COVID-19 increased anxiety, depression for already stressed college students: Study shows unprecedented increase in mental health challenges among undergraduates." ScienceDaily. ScienceDaily, 27 July 2020.

<www.sciencedaily.com/releases/2020/07/200727114731.htm>.

27. Kunwar D, Risal A, Koirala S. Study of Depression, Anxiety and Stress among the Medical Students in two Medical Colleges of Nepal. Kathmandu Univ Med J (KUMJ). 2016; 14(53):22-6.

28. Pokhrel NB, Khadayat R, Tulachan P. Depression, anxiety, and burnout among medical students and residents of a medical school in Nepal: a cross-sectional study. BMC Psychiatry. 2020; 20(1):298.

29. Zigmond AS, Snaith RP. The hospital anxiety and depression scale. Acta Psychiatr Scand. 1983; 67(6):361-70.

30. Risal A, Manandhar K, Linde M, Koju R, Steiner TJ, Holen A. Reliability and Validity of a Nepali-language Version of the Hospital Anxiety and Depression Scale (HADS). Kathmandu Univ Med J (KUMJ). 2015;13(50):115-24.

31. Risal A, Manandhar K, Linde M, Steiner TJ, Holen A. Anxiety and depression in Nepal: prevalence, comorbidity and associations. BMC Psychiatry. 2016; 16(1):102. DOI: 10.1186/s12888-016-0810-0.

32. Centers for Disease Control and Prevention. Excess Deaths Associated with COVID-19. Provisional Death Counts for Coronavirus Disease (COVID-19).2020. https://www.cdc.gov/nchs/nvss/vsrr/covid19/excess_deaths.htm. Accessed 25 Sept 2020.

33. Steimer T. The biology of fear- and anxiety-related behaviors. Dialogues Clin Neurosci. 2002; 4(3):231-49. 
34. Marthoenis M, llyas A, Sofyan H, Schouler-Ocak M. Prevalence, comorbidity and predictors of post-traumatic stress disorder, depression, and anxiety in adolescents following an earthquake. Asian J Psychiatr. 2019; 43:154-9.

35. Holen A, Manandhar K, Pant DS, Karmacharya BM, Olson LM, Koju R, et al. Medical students' preferences for problem-based learning in relation to culture and personality: a multicultural study. International journal of medical education. 2015; 6:84-92.

36. Chew NWS, Lee GKH, Tan BYQ, Jing M, Goh Y, Ngiam NJH, et al. A multinational, multicentre study on the psychological outcomes and associated physical symptoms amongst healthcare workers during COVID-19 outbreak. Brain Behav Immun. 2020; 88:559-65.

37. Global, regional, and national incidence, prevalence, and years lived with disability for 328 diseases and injuries for 195 countries, 1990 2016: a systematic analysis for the Global Burden of Disease Study 2016. Lancet. 2017; 390(10100):1211-59.

38. Herrmann C. International experiences with the Hospital Anxiety and Depression Scale--a review of validation data and clinical results. J Psychosom Res. 1997; 42(1):17-41.

39. Gordon JS, McNew R. Developing the online survey. Nurs Clin North Am. 2008; 43(4):605-19. 